\title{
PTGS1 Gene
}

National Cancer Institute

\section{Source}

National Cancer Institute. PT GS1 Gene. NCI Thesaurus. Code C26596.

This gene plays a role in the regulation of angiogenesis in endothelial cells. 